Vol. 2 No. 3- December 2021

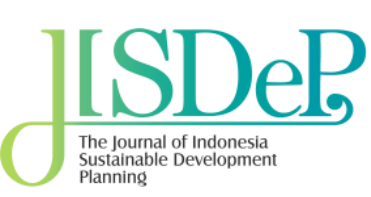

E-ISSN: $2722-0842$ | P-ISSN: $\underline{2721-8309}$

Available online at

Kementerian PPN/

Bappenas

\title{
Discourse for Transition toward Sustainability Development in Industrial Ecology Context in Kutai Kartanegara
}

\section{Dhyna Apriyanti Walidi}

Graduate School of Global Environmental Studies, Sophia University, Tokyo, Japan

d-walidi-5k3@eagle.sophia.ac.jp

\section{Introduction}

A rich ecological value area within East Kalimantan, Kutai Kartanegara, represents a specificparticular ecological system of an island in a tropical country. Covered by the evergreen forest in the past, it has a closed-loop system formed naturally due to its metabolism. This system maintains the high diversity of nature, which provides abundant resources, both renewable and non-renewable. Owing to its ecological system value, the earth has been numerous beneficial the economic sector both for country and region for decades. Coal, as one of the attractive resources for the energy sector, has contributed over $80 \%$ of the GDRP of Kutai Kartanegara in 2010.

Amongst the commitments of countries around the world returning to green resources, coal is still a mainstay to the day due to the low contribution from the other type of regional income such as taxes. The commodity and export value might depict the economic feature of the district from 2013 to 2018. Dinas Perindustrian dan Perdagangan [Disperindag] (2021) reported that coal consistently dominated the export value for Kutai Kartanegara for six years, followed by wood in chips. However, under the revenue sharing mechanism, this sole income has been insignificant for community welfare or reducing poverty in East Kalimantan's highest population region (Martati et al., 2020; Harefa, 2018).

Concerning the contribution of coal mining to the regional income, the proportion does not represent employment by sector. The proportion of GDRP and workforce for the mining sector from total sectors during $2005-2010$ takes around $84.63 \%$ and $7.9 \%$, respectively. In contrast, the agriculture sector,

\section{ARTICLE INFO}

Received: September 25, 2021 Received in revised form: November 21, 2021

Accepted: December 29, 2021
JISDeP - The Journal of Indonesia Sustainable Development Planning Published by Centre for Planners' Development, Education, and Training (Pusbindiklatren),

Ministry of National Development Planning/ National Development Planning Agency (Bappenas), Republic of Indonesia

\author{
Address: Jalan Proklamasi 70, \\ Central Jakarta, Indonesia 10320 \\ Phone: +62 $2131928280 / 31928285$ \\ Fax: +62 2131928281 \\ E-mail: \\ journal.pusbindiklatren@bappenas.go.id \\ Supported by Indonesian Development Planners \\ Association (PPPI)
}


which merely contributes around $6.26 \%$ for GDRP, employed around $44.4 \%$ of the workforce in Kutai Kartanegara (Badan Perencanaan Pembangunan Daerah [Bappeda], 2014b). As the matter of fact, most of the local workforce occupies an inferior position, while the upper-middle position employed workers from outside (Badan Penelitian dan Pengembangan Daerah [Balitbangda], 2017). Apart from the insignificant income for the welfare of the community, I consider the industrial sector in Kutai Kartanegara to be less useful in absorbing local workers regardless of their quality.

The economic base on natural resources extraction implies the depletion rate of the natural resources and waste production. Its aftermath has already blown in the last decades as the accumulative impact as the result of the disturbance on the 'closed-loop system', not to mention the by-product of the industries. Amongst the poor management practice, the environment as the body of the system has been response to negative feedback in receiving the inputs (Kusnadi, 2021). This might result from attenuation in water regulation and service for ecological footprint assimilation toward the security for food, health, livelihood, and shelter (Bappeda, 2014a; Hansen et al., 2017; Susilowati \& Leksono, 2013). The record for social conflicts for mining activity is the loss of land and livelihood of many of the people, including the depletion of buffer area for paddy rice. Even worse, the poor mining practice under weak environmental management aggravates the rate of degradation, and the frequency of disaster compound the conflicts (Pujiriani et al., 2015). The number of disasters for two years (2018-2020) is more frequent by years (Koran Kalimantan Timur, 2021), yet less spatial and temporal monitoring data to explain the phenomena.

The cost for the ecosystem damage presumably corresponds to a Ministry of Environmental and Forestry study in 2013. The natural capital of Kutai Kartanegara counted in Net Present Value (NPV), was lost around Rp. 581,43 trillion by mining activity (Suastha \& Kandi, 2016). The economic motives coupled with the need for energy globally constitute the driver extraction and expansion to comply with the energy demand either for local or global. Over the decades, this ecosystem became a supply chain for the primary industry that relied on its natural resources (Indonesia-Investments, 2021; Statistical Review of World Energy, 2021). The awareness of these perils increased due to global concern for sustainability. Nevertheless, down-level governance did not fully understand the strategy and has a classical operational issue.

Kutai Kartanegara occupies the highest level of mining licensing on a national scale until 2009. Around 687 or two licenses per village from a total of 227 villages were noted (Kurnain. et al., 2012). The Mining Advocacy Network Data shows around 625 from 1,190 mining licenses in East Kalimantan are being in this district. Amongst those licenses, around 90 are in Samboja, one of two areas for the new capital city of Indonesia. Based on the Badan Pusat Statistik [BPS] (2017) survey, the survey classifies the big scale industry and middle scale industry on a scale of $\geq 100$ labors and 20-99 laborers, respectively. Those represent around 11 oil palm processing plants (CPO and palm kernel) for the big scale industries, and around 8 big scales to middle scale industries for other sectors (comprise of energy, heavy equipment, transportation, wood, electricity, and service). In addition, Plantation Service data shows around 15 mills of oil palm processing for 50 oil palm plantation companies were in Kutai Kartanegara until 2016.

The booming of oil palm plantations that opened in rural areas and its striking growth undoubtedly have changed the rural ecology (Dharmawan et al., 2016). Known as the widest peat hydrological area in East Kalimantan, this middle stream of the Mahakam watershed has been recognized as the Mahakam cascade because of its ecological feature. It has appointed as a provincial strategic area as socialized by Dinas Lingkungan Hidup Kalimantan Timur [DLH] (2020) recently. However, the expansion area of oil palm plantations is presumably associated with the alteration of the lake and river in Kutai Kartanegara. The lakes near the oil palm farm have desiccated and the waters have been cloudy. It is compounded by aquatic biota reduction as recognized by the local community leader. They reported that the alteration of peat ecology showed water stress due to peatland drainage. The river is burdened by erosion mud, and the water is polluted due to becoming the route for coal transportation (Dharmawan et al., 2016). In contrast with the abundance of resources, many isolated villages lack electricity (Dinas Energi dan Sumber 
Daya Mineral [ESDM], 2019) or clean water. Amidst the festive competition in depleting the natural resources, the inequality development in this energy barn region more justifies the paradox of the rich region.

Industrial activities are regarded as the major environmental impact contributor, so that the application of industrial ecology is critical to its sustainability. The mutual value exchange amongst the environment and its inherent aspects, such as natural resources, community, and industry, in a certain geographical space corresponds to the Industrial Ecology definition. Furthermore, the presence of industries among communities and policymakers is a potential for industrial ecology application. The application is not merely helpful to optimize the environmental performance for the company but also provides additional value both for companies and local people. I proposed IE to solve the electrification rate problem because of geographical limitations, reducing fossil fuel consumption for the energy sector, reducing waste generation and waste production, outright to creating wealthiness for local people and equality development. Therefore, the local government is a driving actor among the networking partner for IE applications. They are also determining the success of IE application by providing a transformation pathway through its function in establishing the platform, regulating, facilitating, and coordinating.

Concerning the existing situation of environmental issues which interconnected with society and the economy, I argued that the solution by sector could not solve the complexity of the issue chain. However, it is not too late for transformation to start from paradigm-shifting related to the sustainable development concept. The concept of development ensures the plan and manifestation of the current need without sacrificing the living of the next generation. The presence of industries amidst environmental, social, and economic concerns can be designed for Industrial Ecology implementation for sustainable development.

We based the reliability of the sustainable development paradigm on a scientific aspect that is measurable and empirically examined both for the development planning and policy. The challenge in sustainable development implementation is how to embed science in planning and policy. Thus a baseneed approach is required, entailed with its analysis using an understandable scientific concept to produce a compatible tool or framework with planning and policy. The Industrial Ecology concept not merely offered measurable and empirical processes, but may ensure the integration of the sustainability pillars in planning and development.

\section{Communicating Sustainability from Industrial Ecology Perspective}

The fundamental definition of the IE concept is learning from and applying the concept of the natural system. Many countries in Asia (Berkel et al., 2009; Ban et al., 2015; Xiang \& Yuan, 2019) and Europe (Lyakurwa, 2014; Domenech et al., 2019) have adopted it in various models to establish or promote a system (Xiang \& Yuan, 2019; Raimbault et al., 2020) for sustainable development. However, using the metaphor both for understanding and communicating IE into more familiar domains is extremely needed (Johansson, 2001). Inspired by Wennersten and Gröndahl (2001), that Industrial Ecology is a metaphor of the natural system and its metabolism, thus it bases the system of thinking to develop the sustainable development plan. The dependence of all economic systems on the biosphere reinforces the role of the development model in considering the global biogeochemical cycles at a national or regional level. The global level evidence has shown that anthropogenic activities around the world interfere with the natural system and introduce many substances to the biosphere (Smill, 2001). Due to the continued global impact, many plausible technicals and socioeconomic adjustments may be taken for effective adaptation. Thus, "marrying" the industry and environment for exchanging the input and output is highly suggested rather than contradicting the two.

Climate Change will effects humans globally with floods and drought even though the activities hold locally. An unsustainable environmental theorem in industries practice will eventually threaten their business sustainability with the presence of environmental impact by its activities. The commitment of 
industry sectors to reduce emission under $2^{\circ} \mathrm{C}$ (Paris Agreement, 2015) and emission target to achieve $1.5^{\circ} \mathrm{C}$ (Intergovernmental Pannel on Climate Change [IPCC], 2018) eventually urge the corporation to adjust their environmental performance. Owing to the commitment, the global industrial sectors have changed towards a sustainable business strategy through the determination of carbon performance to ensure the link of their supply chains corresponds to sustainable practices (Transition Pathway Initiative, 2021). The raw material derived from unrenewable resources or energy will eventually abandon and shift into a sustainable business model. The innovation and technology competition by the industrial sector has reached the stage of breaking away from unrenewable source dependence, both for high-carbon footprint and high-water footprint material origin. Thereby, the country that relied on natural resources extraction for economic will certainly have more serious concerns than those existing problems.

Sustainable Development Report 2021 recently ranked Indonesia at 97th out of 165 countries in sustainable development performance. The low expenses for research and development seem related to the paltry amount of scientific articles. This leads to industry, innovation, and infrastructure weakness, as shown in the 9th SDG (United Nations, 2021). Some indicators cannot be complemented because of the unavailability of data input. The lack of clean water and sanitation indicators, social discrepancy, irresponsibility of consumption and production, climate action, and partnership is the reason for the unavailability of solutions and innovations.

The perspectives of IE can be useful by emphasizing its critical need for specific environmental analysis and decision-making purposes (Lifset \& Graedel, 2001). The connectedness among the existing issues ought to include the local sustainability problem and resources potential. Both of them intended to answer the fact of less electrification ratio in the area well-known as the energy barn for country and world globally. The connectedness concept in IE perspective offered a solution to promote environmental quality and additional values for society and industry. It precedes by the resources analysis among the entities in the myriad landscape of the area and promises the development model which able to create an independent and sustainable economic source.

We should clearly define the objectives of IE application and its focus, though it involves a multidimension approach. IE adoption means adopting its concept, processes, tools, and management as a comprehensive approach to achieve the goal. The ability of IE to integrate with the widespread applicable method is to support its comprehensiveness, including to assure the implementation corresponds to the system. I propose the core idea in IE to be associated with and optimize the existing development plan. An acknowledgment that the IE model ought to implement in one package and in a long-term period for continuous improvement. By means of these, the IE model's success is more promising than implementing a rhetorical-sophisticated solution.

The effectiveness of IE application has been observed the need for sustainability and suggested the applicability of IE for sustainable social, economic, political, and environmental performance for government both in developed and developing countries (Lyakurwa, 2014). The sharing processes both for resources and by-products among industries, power stations, and public facilities in Kalundborg are examples of IE utilization by government and industries. As for the successful implementation of IE ideology by government and industries, they mentioned it as the vital role of a country in providing policy and legal framework both for support and enforcing the environmental laws (Berkel et al., 2009). Having the local institutional structure together with regulation is necessary to support IE implementation. They have claimed that the largest barriers to the success of IE implementation on the grassroots level are caused by the poor community service and the lack of social legitimacy due to political integrity (Opoku, 2004). Both the former and the latter show that embedding the IE in politics should be considered seriously. Other findings convinced that a careful contextualized and a localized need-linked effort can shift the models of an industrial ecological system to become meaningful politically (Salmi \& Toppinen, 2007). I am convinced that some respective research foregoing has redefined or translated the scientific community needs through scientific concepts and ideas into a more understandable definition. 
Furthermore, the government needs to consider the incorporation of the concept into planning and policy as a significant political strategy to support sustainable development.

\subsection{Framing Science into Policy}

Framing the development goal based on the IE context is reliable and effective, including embedding IE into politics. Salmi \& Toppinen (2007) probes the mechanism of embedding scientific ideas through a framework analysis for wide use. Even though it was a scientific idea and policy instrument at its initialization, yet they have used it for the natural resources management model. It has provided a breakthrough in problem-solving both ecologically and economically of where it was originated, the Kola Peninsula. There are several important aspect analogs of IE or what is so- called complex utilization. First, the metaphors and boundaries object of the natural resource ought to be set accordingly. Second, the proposed model should integrate a system and support connectedness in demand (input) and production (output) among the entities local and or regional scale (Salmi \& Toppinen, 2007). The translation effort of the scientific context and IE should undergo issue framing and comprehension building into action. Appointing a particular aspect to communicate the issue is suggested prior to comprehending it to embody the guidelines. Addressing the environmental damage as the result of poor industrial practice based on facts is a framing example for a careful environmental design where the waste production should consider the existence of nature and its components (Salmi \& Toppinen, 2007).

\subsection{Redefining and Translating IE Through Understandable Definition}

Introducing IE as a sustainability tool provides the holistic framework for guiding the transformation. The conceptual approach of closed-loop ecosystem characteristic is underlying the system of thinking in replicating and simulating the environmental design. Visualization of an engineering system is better to comprehend the processes, examine the design, and optimize the model rather than a mere rhetorical form of guideline. The transformation of qualitative information into an accountable manner (measurable) to result in the applicable tools is promising practical use as the plan and development tool.

\subsection{The Connectedness of Sustainable Development Goals-Government Program}

The connectedness between government programs with or aligned with SDGs might provide an opportunity to introduce and embed IE. Interpreting the national strategic plan, which aligns with SDGs seems not fully understood by local government and cannot communicate at the operational level. Even though this problem is still vague yet obviously, the implementation is not fruitful regarding its alignment with SDG. In addition, the breakdown of local government programs does not reflect the necessity of this alignment in managerial and operational level performance.

Since IE ought to implement in a full package to convince its success, embedding IE in local government programs provides a new discourse and might be helpful for government target achievement because it is aligned with SDGs. In addition, this package might provide a discourse for guidelines on performance standards of governance improvement at each stage, from managerial to operational. 


\section{Transformation Preparedness}

\subsection{Strategy, Policy, and Legal Framework}

Based on the findings of the barriers to developing the connectedness (the Industrial Symbiosis), the combination of authority, public participation, and partnership might propose. They addressed the collaboration of these governance modes to support the sustainable development model in the IE context lately (Sodergen \& Palm, 2021). The strategy and policy correspond to the aim is a precedent in transformation processes for further developing the respective legal framework. Pertaining to the IE implementation, these entities are subject to comprehensive analysis, such as the potential exchange value (trade-off), existing initiatives, and applicable regulation.

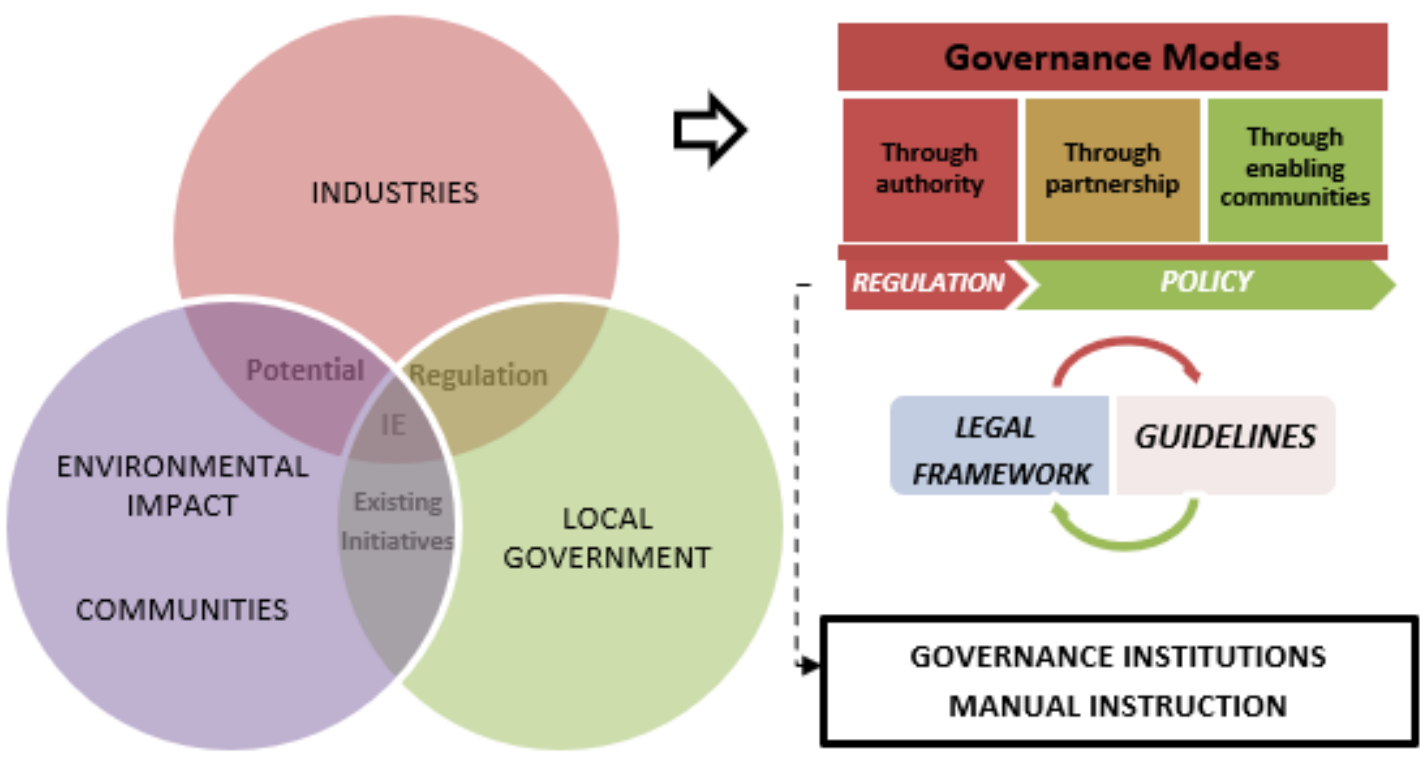

Figure 1. Strategy, Policy, and Legal Framework

The practical guidelines for public authorities and business development organizations on developing and implementing the Industrial Symbiosis of the ecosystem and good practice of IS in the Baltic Sea Region might be adapted to local conditions. Conditioning the pathway for transformation can achieve by developing a legal framework to regulate:

a. Mainstreaming the corporate social responsibility towards IE development.

b. Promoting the connectedness advantages among actors through education in a broad sense, simplification of the access for the public, and capacity building under their role.

c. Localizing Industries and research institute linkage to ensure the sustainability business of the private sector.

d. Integrating the development of the instrument package into the vision and strategic roadmap to ensure its continuity for future scenario plans.

e. Mapping the entities along with its material flow and shared information among respective actors.

f. Rewarding and promoting initiatives and talents contribution according to the alignment or best practice of the connectedness system among stakeholders. 
g. Local and regional potential mapping regarding the connectedness strength, including local people for innovation and entrepreneur discovery.

h. Establishing solid networks and trusted systems to cultivate and maintain an active leadership role among respective actors.

i. Recognizing leading industrial role in coordinating the connectedness platform about the interest of their business sustainability.

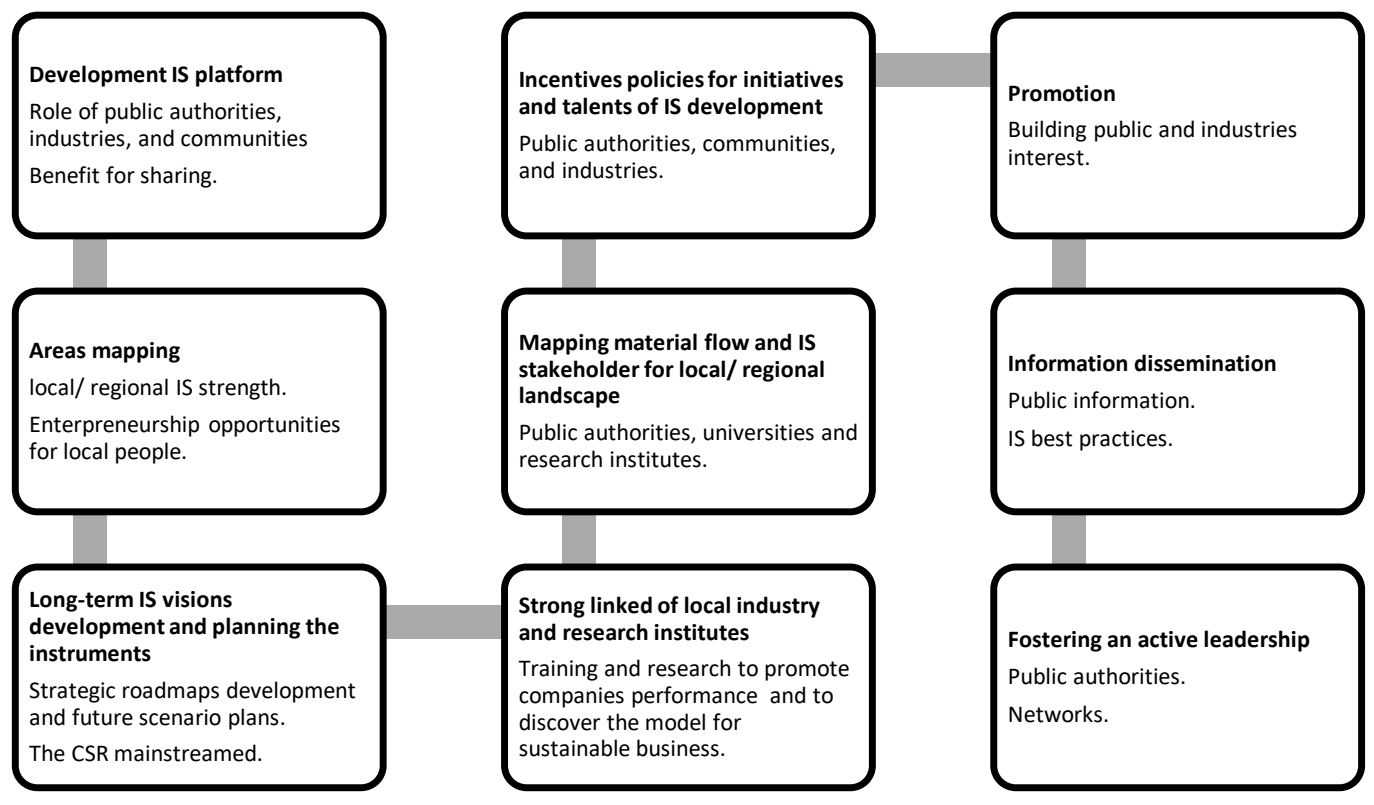

Figure 2. Adopting guidelines for transformation pathway

Amidst the global goals for sustainability, the industrial symbiosis financing models of the private sector are many to be adopted as the platform. We must understand the collectivity and connectivity regarding the global action in leading the sustainable development paradigm as an opportunity for affiliation and collaboration (Xiang \& Yuan, 2019), notably for the third world countries amid a whirlpool of sustainability issues. The role of local government in promoting the initiatives and good practice of sustainability are critical to providing connection nodes for collaboration globally.

\subsection{Document Planning}

A spatial agent-based model is recommended for a complex system where the industry activities together with its waste are concomitantly exist in a geographical feature and space, including the inherent aspects that might affect. It has been used where the dynamic of a sustainable economy and its network is necessary to model. The presence of prescribed rules or boundaries among the interactions enables the observation of system behavior. This spatial arrangement-based model offers the ability to include the empirical data based on the boundary and the flexibility to use in various objectives, entailed with the analysis (Raimbault et al., 2020). An incentives policy might be proposed concerning the lack of data and information as a classical problem in local government. This could encourage the performance of empirical data achievement, including information sharing. The diagrams below visualize the self- governance of local government for planning. 


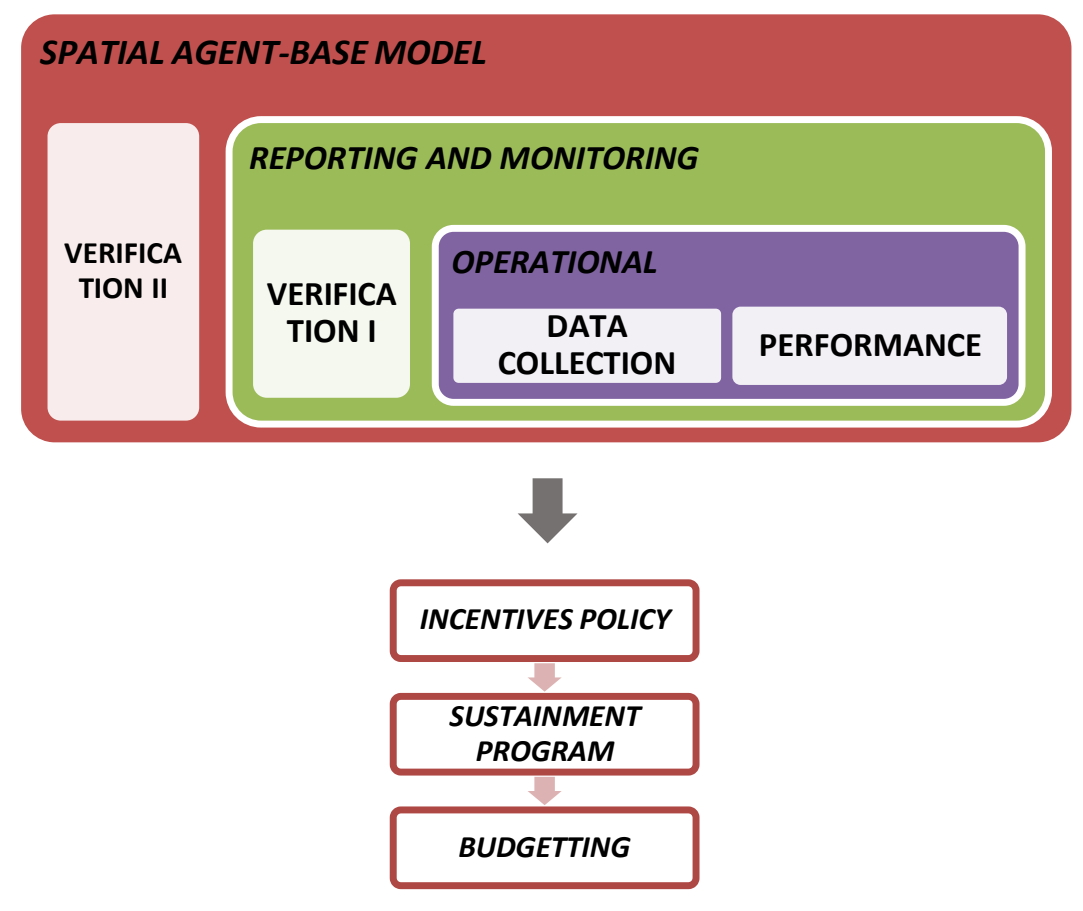

Figure 3. Self-governance for planning

\subsection{Enabling Community Engagement.}

According to recent research, linking government through enabling shows the strongest correlation between local government and IS network (Sodergen \& Palm, 2021). I mainly addressed it to overcome the barriers for local government as economic, regulatory, social, and information through integrating and coordinating the actors within the network. Lack of willingness to collaborate and social isolation between organizations depend on how local government effort to convince the public through their function in promoting, facilitating, building the network for industrial symbiosis. The local government also can play a role as a knowledge broker and provide a platform for joint data and information sharing to overcome the lack of community awareness and technical knowledge.

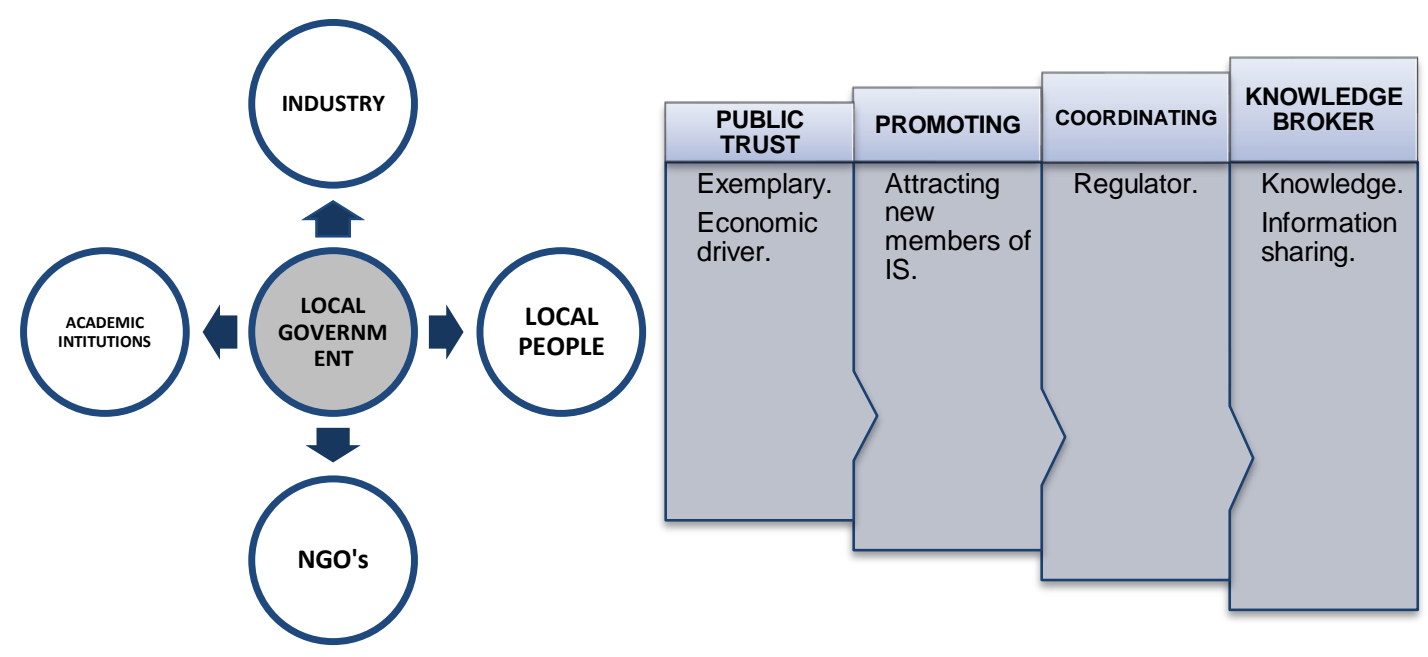

Figure 4. Governance Mode by Enabling IS Network 


\section{Proposing a Framework for IE Implementation}

The local government might start from the existing initiative to develop program alignment with IE to linked. Here is the district government program linked Industrial Ecology concept.

Table 1. The connectedness of existing programs and initiatives with the IE concept.

\begin{tabular}{|c|c|c|c|c|c|}
\hline $\begin{array}{c}\text { Philosophy of } \\
\text { Current } \\
\text { Development (2021- } \\
\text { 2026) }\end{array}$ & Mision & $\begin{array}{l}\text { Environmental and } \\
\text { Forestry Program }\end{array}$ & $\begin{array}{c}\text { Program } \\
\text { Description }\end{array}$ & $\begin{array}{c}\text { Ongoing } \\
\text { initiatives } \\
\text { and/or service }\end{array}$ & $\begin{array}{l}\text { Proposing } \\
\text { Framework }\end{array}$ \\
\hline Innovative & 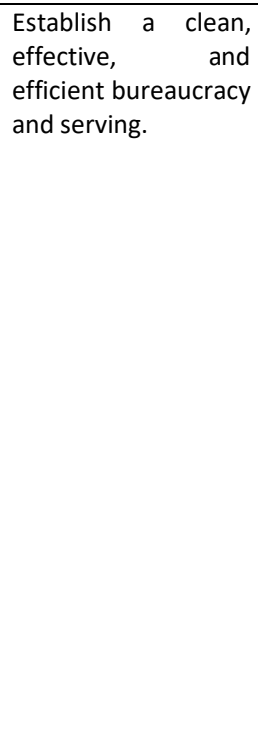 & $\begin{array}{l}\text { Environmental- } \\
\text { Friendly Village } \\
\text { Environmental } \\
\text { Awareness } \\
\text { Environmentally } \\
\text { friendly business } \\
\text { practice }\end{array}$ & $\begin{array}{l}\text { Incentives for } \\
\text { environmentally } \\
\text { friendly } \\
\text { management } \\
\text { Monitoring waste } \\
\text { management, its } \\
\text { including and } \\
\text { facilities } \\
\text { infrastructures. } \\
\text { Strengthen } \\
\text { Environmental } \\
\text { Impact Assessment } \\
\text { and facilitate one } \\
\text { million trees at } \\
\text { reforestation and } \\
\text { reclamation area. }\end{array}$ & $\begin{array}{l}\text { Environmental } \\
\text { Protection and } \\
\text { Conservation } \\
\\
\text { Environmental } \\
\text { Impact } \\
\text { Assessment } \\
\text { and } \\
\text { environmental } \\
\text { law } \\
\text { enforcement }\end{array}$ & $\begin{array}{l}\text { Innovation, } \\
\text { promotion, } \\
\text { and } \\
\text { information } \\
\text { disseminati } \\
\text { on. } \\
\text { Monitoring } \\
\text { through } \\
\text { industrial } \\
\text { ecology } \\
\text { design. } \\
\text { Industrial } \\
\text { ecology } \\
\text { design based } \\
\text { on } \\
\text { geographical } \\
\text { featuresand } \\
\text { environme } \\
\text { ntal impact } \\
\text { assessment. }\end{array}$ \\
\hline Competitiveness & $\begin{array}{l}\text { Improving human } \\
\text { resources } \\
\text { development within } \\
\text { noble, prominent, } \\
\text { and ethical. }\end{array}$ & $\begin{array}{l}\text { Environmental } \\
\text { Awareness }\end{array}$ & $\begin{array}{l}\text { Incentives for } \\
\text { environmentally } \\
\text { friendly } \\
\text { management }\end{array}$ & $\begin{array}{l}\text { Forest } \\
\text { management } \\
\text { and } \\
\text { conservation }\end{array}$ & $\begin{array}{l}\text { Incentives } \\
\text { policies for } \\
\text { initiatives } \\
\text { and talents } \\
\text { of IS } \\
\text { developme } \\
\text { nt and } \\
\text { fostering } \\
\text { active } \\
\text { leadership. }\end{array}$ \\
\hline Autonomous & $\begin{array}{l}\text { Improving } \\
\text { environmentally } \\
\text { friendly } \\
\text { management of the } \\
\text { natural resources. } \\
\\
\text { Strengthening } \\
\text { economy-based } \\
\text { agriculture and } \\
\text { development ative economy. } \\
\text { creative }\end{array}$ & $\begin{array}{l}\text { Environmental- } \\
\text { Friendly Village } \\
\text { Environmental } \\
\text { Awareness } \\
\text { Environmentally } \\
\text { friendly business } \\
\text { practice }\end{array}$ & 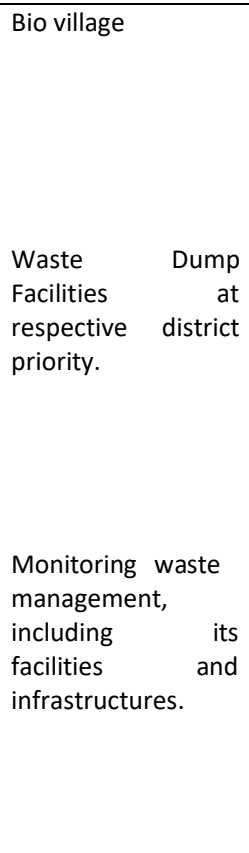 & $\begin{array}{l}\text { Land carrying } \\
\text { capacity } \\
\text { inventory } \\
\text { Land carrying } \\
\text { capacity } \\
\text { inventory and } \\
\text { environmental } \\
\text { protection and } \\
\text { conservation. } \\
\text { Impact } \\
\text { Assessment }\end{array}$ & $\begin{array}{l}\text { Symbiosis } \\
\text { environme } \\
\text { ntal design } \\
\text { based on } \\
\text { geographical } \\
\text { features. } \\
\text { Industrial } \\
\text { symbiosis } \\
\text { design based } \\
\text { on } \\
\text { geographical } \\
\text { features and } \\
\text { risk } \\
\text { assessment. } \\
\text { Industrial } \\
\text { ecology } \\
\text { design based } \\
\text { on } \\
\text { geographical } \\
\text { features and } \\
\text { environme } \\
\text { ntal impact } \\
\text { assessment. }\end{array}$ \\
\hline
\end{tabular}




\begin{tabular}{|c|c|c|c|c|c|}
\hline $\begin{array}{c}\text { Philosophy of } \\
\text { Current } \\
\text { Development (2021- } \\
\text { 2026) }\end{array}$ & Mision & $\begin{array}{l}\text { Environmental and } \\
\text { Forestry Program }\end{array}$ & $\begin{array}{c}\text { Program } \\
\text { Description }\end{array}$ & $\begin{array}{c}\text { Ongoing } \\
\text { initiatives } \\
\text { and/or service }\end{array}$ & $\begin{array}{l}\text { Proposing } \\
\text { Framework }\end{array}$ \\
\hline & $\begin{array}{l}\text { Improving the } \\
\text { quality of basic } \\
\text { infrastructure and } \\
\text { connectivity among } \\
\text { regions. }\end{array}$ & $\begin{array}{l}\text { Environmentally } \\
\text { friendly business } \\
\text { practice }\end{array}$ & $\begin{array}{l}\text { Monitoring waste } \\
\text { management, } \\
\text { including its } \\
\text { facilities and } \\
\text { infrastructures. }\end{array}$ & $\begin{array}{l}\text { Environmental } \\
\text { Impact } \\
\text { Assessment }\end{array}$ & $\begin{array}{l}\text { Symbiosis } \\
\text { design based } \\
\text { on } \\
\text { geographical } \\
\text { features. }\end{array}$ \\
\hline
\end{tabular}

Source: Vision and Mision of KUKAR IDAMAN (2021-2026) and Program of Dinas Lingkungan Hidup dan Kehutanan (2021).

Meanwhile, Regional Spatial Planning Service and Environmental and Forestry Service have an ongoing program that could be considered the ongoing initiatives with potential for IE framework implementation. Further outlook is needed to evaluate to what extent those initiatives and/or services on its achievement to support the requirement for the framework.

\begin{tabular}{|l|}
\hline Ongoing Initiatives and or/ service \\
\hline - Regional spatial change \\
- Environmental Protection and Conservation \\
- Environmental Impact Assessment \\
- Environmental Law Enforcement \\
• Forest management and conservation
\end{tabular}

\begin{tabular}{|l|}
\hline \multicolumn{1}{|c|}{ Requirement for framework } \\
\hline - Mapping the entities \\
- Licensing issuance \\
- Defineing the boundary \\
-Material flow \\
- Material flow \\
- Company environmental management \\
- Corporate social responsilbility \\
- Public trust \\
- Connectedness of government institution, local \\
people, NGO's,and academic institutions.
\end{tabular}

Figure 5. Potential support for framework requirement

This linkage merely connects the current development program with two institution programs. The connectedness among other institutional programs is strongly suggested to enhance the effectiveness and efficiency both for budgeting and controlling and to increase the potential of value exchange. Even though a wider pattern connectedness will provide more potential exchange value within the system, further analysis of the technical potential and limitations should be considered. 


\section{Conclusions}

Sustainable development requires a transformation that collectively encompasses governance, the industrial sector, and society to synergize and adapt with sustainability instrumentation. Even though this transformation process requires a long-term period in its goal, it is not too late to begin. The lack of infrastructure in a developing country could be regarded as an opportunity for infrastructure development through environmental planning and design, which aligned the development model. As a result, infrastructure development costs might be efficient and can optimize according to achievement level and sustainable development target.

The initiatives aligned with sustainable development are essential to entail and adjust with sustainable development model framework to speed up the transformation processes. The transformative policies are mandatory as sustainability instrument packages that ensure the implementation until the operation level. Last but not least, it should apply the instrument thoroughly for sustainability and completion to ensure the success of the sustainable development model. The transformation requires full support from the whole stakeholder and society and a political sacrifice. This is because the transformative policies in practice often faced the political interest and business as usual. Nevertheless, the transformation will determine development sustainability and secure the current and future livelihood.

\section{References}

Badan Perencanaan Pembangunan Daerah. (2014a). Rencana program investasi jangka menengah 20142018: Profil Kabupaten Kutai Kertanegara.

Badan Perencanaan Pembangunan Daerah. (2014b).Rencana program investasi jangka menengah terpadu 2014-2018: Aspek sosial dan ekonomi. (228-237).

Badan Penelitian dan Pengembangan Daerah. (2017). Study of local workforce competitiveness in meeting the need of business sector in Kutai Kartanegara. Journal of Gerbang Etam, 17(1).

Badan Pusat Statistik. (2017). Statistik Industri Besar-Menengah di Kalimantan Timur (Publication No. 64530.1909). https://kaltim.bps.go.id/publication/2019/12/20/2f1c514b94583b4df5c2180b/statistikindustri- besar-sedang-provinsi-kalimantan-timur-2017.html.

Ban, Y.U., Jeong, J.H., \& Jeong, S.K. (2015). Assessing the performance of carbon dioxide emission reduction of commercialized eco-industrial park projects in South Korea. Journal of Cleaner Production, 114, 124-131. https://doi.org/10.1016/j. jclepro.2015.09.083

Berkel, V. R., Fujita, T., Hashimoto, S., Fujii, M. (2009). Quantitative assessment of urban and industrial symbiosis in Kawasaki, Japan. Environmental Science \& Technology, 43(5), 1271-1281. https://doi.org/10.1021/es803319r.

Dharmawan, A.H., Mardiyaningsih, D.I., Yulian, B.E. (2016). The expansion of oil palm plantation and the change of social, economic, and ecology of the rural: A case study in Kutai Kartanegara. Project Working Paper Series OPAL, 1.

Dinas Energi dan Sumber Daya Mineral. (2019). Laporan Kinerja Institusi Pemerintah. Kutai Kartanegara. https://prokom.kukarkab.go.id/dokumen/36ded790-af77-11ea-99e8-93eece7dc30a/dokumen.

Dinas Lingkungan Hidup Kalimantan Timur. (2020). Sosialisasi danau kaskade Mahakam. https://dinaslh.kaltimprov.go.id/

Dinas Perindustrian dan Perdagangan. (2021). Nilai ekspor dan komoditi Kabupaten Kutai Kartanegara 2013-2018. https://disperindag.kukarkab.go.id/dataku/elemen/perdagangan/komoditi-ekspor

Domenech, T., Bleischwitz, R., Doranova, A., Panayotopoulos, D., Roman,L. (2019). Mapping industrial symbiosis development in Europe-typologies of networks, characteristics, performance, and contribution to the circular economy. Resources, Conservation, and Recycling Journals, 141, 76-98. https://doi.org/10.1016/J.RESCONREC.2018.09.016

Hansen, Oktaviani, L.W., \& Susanti, E.W. (2017). Mahakam River water quality on Public Health in Loa Duri Ulu Sub-District, Loa Janan District, Kutai Kartanegara Samarinda. Journal of Sangkareang Mataram, 3(4), (2355-9292). 
Harefa, M. (2018). Relationship of revenue sharing with regional revenue and poverty in East Kalimantan Province. Economy and Public Policy Journal, 9(2). https://doi.org/10.22212/jekp.v9i2.1159

Indonesia-Investments (2021). Coal. https://www.indonesia-investments.com/id/bisnis/komoditas/batubara/item236.

Intergovernmental Pannel on Climate Change. (2018). Global Warming of $1.5^{\circ} \mathrm{C}$. Special Report. https://www.ipcc.ch/site/assets/uploads/sites/2/2019/06/SR15_Full_Report_High_Res.pdf

Johansson, A. (2001). Industrial ecology and industrial metabolism. In R. U. Ayres \& L. W. Ayres. (Eds.), A handbook of industrial ecology (p. 70). https://doi.org/10.1017/S1466046603261123

Koran Kalimantan Timur. (2021, February). Wilayah Kutai Kartanegara rawan bencana. Koran Kaltara. https://korankaltara.com/wilayah-kukar-rawan-bencana-alam/

Kurnain, A., Nasruddin, \& Stiadi. D., (2012). Land capacity analysis of post coal mining area for leading economic area (case in Kutai Kartanegara Regency). National Priority Research of Masterplan for Acceleration and Expansion Development Economic of Indonesia. http://eprints.ulm.ac.id/8170/1/22_Laporan\%20Akhir\%20MP3EI_AhmadKurnain.pdf

Kusnadi. (2021). Fenomena penurunan kualitas air akibatkan ribuan ikan tambak mati mendadak. Info Publik. https://infopublik.id/kategori/nusantara/539955/fenomena-penurunan-kualitas-airakibatkan-ribuan-ikan-tambak-mati-mendadak

Lifset, R \& Graedel, T.E. (2001). Goals and Definition. In R. U. Ayres \& L. W. Ayres (Eds.), A handbook of industrial ecology (pp. 3). https://doi.org/10.1017/S1466046603261123

Lyakurwa, F.S. (2014). Industrial ecology a new path to sustainability: An empirical review. Independent Journal of Management and Production. https://doi.org/10.14807/ijmp.v5i3.178

Martati, I., Asniwaty, B., \& Suminto. (2020). The impact of regional income to welfare of regencies and cities community in East Kalimantan Indonesia. Academy of Entrepreneurship Journal, 26(1).

Opoku, H.N., (2004). Policy implications of industrial ecology conceptions. Business Strategy and the Environment, 13(5), 320-333. https://doi.org/10.1002/bse.417

Paris Agreement. (2015). United nations climate change convention. https://unfccc.int/process-andmeetings/the-paris-agreement/the-paris-agreement

Pujiriani, D.W., Puri, W.H., \& Salim, M.N. (2015). Strategic Research Report: Land provision policy supports food security in Kutai Kertanegara Regency, East Kalimantan Province.. Centre of Research and Community Service of National High School. http://repository.stpn.ac.id/811/1/4\%20Kutai\%20Kertanegara.pdf

Raimbault, J., Broere, J., Somveille, M., Serna, J.M., Strombom, E., Moore, C., Zhu, B., \& Sugar, L. (2020). A spatial agent-based model for simulating and optimizing networked eco-industrial systems. Resources, Conservation, and Recycling Journals, 155, 104538. https://doi.org/10.1016/j.resconrec.2019.104538

Salmi, O \& Toppinen, A. (2007). Embedding science in politics. "complex utilization" and industrial ecology as models of natural resources use. Journal of Industrial Ecology. https://doi.org/10.1162/jiec.2007.1256

Smill, V. (2001). Global biogeochemical cycles. In R. U. Ayres \& L. W. Ayres (Eds.), A handbook of industrial ecology (p. 249). https://doi.org/10.1017/S1466046603261123

Sodergen, K \& Palm, J. (2021). The role of local governments in overcoming barriers to industrial symbiosis. Journal of Cleaner Environmental System, 2, 100014. https://doi.org/10.1016/j.cesys.2021.100014

Statistical Review of World Energy. (2021). Statistical review of world energy full report 70th edition. https://www.bp.com/content/dam/bp/business-sites/en/global/corporate/pdfs/energyeconomics/statistical-review/bp-stats-review-2021-full-report.pdf

Suastha, R. D \& Kandi, R. D. (2016). Coal exploitation, Kutai Kartanegara loss Rp. 581 trillion. CNN Indonesia. https://www.cnnindonesia.com/nasional/20160907001450-20-156556/eksploitasibatubara-kutai-kartanegara-rugi-rp581-triliun

Susilowati, Y \& Laksono, B.E. (2013, February). Environmental damage analysis in East Kalimantan Region based on Mahakam River water quality. Proceedings of the 50th National Seminar on the Indonesian Chemical Cooperation Network, Yogyakarta. http://lipi.go.id/publikasi/analisis-kerusakanlingkungan-wilayah-kalimantan-timur berdasarkan-kualitas-air-sungai-mahakam/646\

Transition Pathway Initiative. (2021). Carbon performance. https://www.transitionpathwayinitiative.org/sectors 
United Nations. (2015). Paris agreement. https://unfccc.int/process-and-meetings/the-parisagreement/the-paris-agreement

United Nations. (2021). The sustainable development goals report. https://unstats.un.org/sdgs/report/2021/The-Sustainable-Development-Goals-Report-2021.pdf

Wennersten, R \& Gröndahl, F. (2005, June 12-15). The relation of industrial ecology versus natural ecosystem, and the fundamental principles for industrial ecology in anthropogenic system [Conference session]. The 3rd International Conference Industrial Ecology for a Sustainable Future. Stockholm.

Xiang, P \& Yuan,T. (2019). A collaboration-driven mode for improving sustainable cooperation in smart industrial parks. Resources, Conservation, Recycling Journals, 141, 273-283. https://doi.org/10.1016/j.resconrec.2018.10.037 